\title{
The Use of Audio Media to Improve The Story Of Class III Students of SD Negeri Cibentang 02 Bantarkawung
}

\author{
Lailatul Qudsiyah
}

SDN Cibentang 02

qudsiyahlailatul@gmail.com

\author{
Article History \\ accepted 01/11/2020
}

approved 08/11/2020

published $15 / 11 / 2020$

\begin{abstract}
This study aims to determine the improvement of story listening skills in grade III SD Negeri Cibentang 02 by utilizing audio media. The form of this research is classroom action research. The research was conducted at SD Negeri Cibentang 02 in grade III students. The data collection techniques used were observation and assignments.

This research procedure is based on classroom action research procedures, namely: (1) planning, (2) implementation, (3) observation, and (4) reflection. The results of this study, namely that there was an increase in student learning outcomes and the quality of learning listening skills using audio media in class III SD Negeri Cibentang 02, namely as follows: (1) The average value of student learning outcomes on the pre-action test was 66 and became 70 in cycle I, then increased to 76 in cycle II and become 80 in cycle III; and (2) Student activity or student involvement during learning in cycle I reached $82 \%$ and increased to $89 \%$ in cycle II and increased again to $92 \%$ in cycle III. The improvement in the quality of learning outcomes is marked by the increasing number of students who reach the completeness limit set by SD Negeri Cibentang 02.
\end{abstract}

Keywords: audio media, story listening skills, Indonesian language learning.

\begin{abstract}
Abstrak
Penelitian ini bertujuan untuk mengetahui peningkatan keterampilan menyimak cerita pada siswa kelas III SD Negeri Cibentang 02 dengan memanfaatkan media audio. Bentuk penelitian ini adalah penelitian tindakan kelas. Penelitian dilaksanakan di SD Negeri Cibentang 02 pada siswa kelas III. Teknik pengumpulan data yang digunakan adalah observasi dan penugasan.

Prosedur penelitian ini didasarkan pada prosedur penelitian tindakan kelas, yaitu : (1) perencanaan, (2) pelaksanaan, (3) observasi, dan (4) refleksi. Hasil penelitian ini, yaitu terdapat peningkatan terhadap hasil belajar siswa dan kualitas pembelajaran keterampilan menyimak menggunakan media audio pada siswa kelas III SD Negeri Cibentang 02, yaitu sebagai berikut: (1) Nilai rata-rata hasil belajar siswa pada tes pratindakan adalah 66 dan menjadi 70 pada siklus I, kemudian meningkat menjadi 76 pada siklus II dan menjadi 80 pada siklus III; dan (2) Aktivitas siswa atau keterlibatan siswa selama pembelajaran pada siklus I mencapai $82 \%$ dan meningkat menjadi $89 \%$ pada siklus II danmeningkat lagi menjadi $92 \%$ pada siklus III. Peningkatan kualitas hasil pembelajaran ditandai dengan meningkatnya jumlah siswa yang mencapai batas ketuntasan yang ditentukan oleh SD Negeri Cibentang 02.
\end{abstract}

Kata kunci: media audio, keterampilan menyimak cerita, pembelajaran bahasa Indonesia.

Social, Humanities, and Education Studies (SHEs): Conference Series https://jurnal.uns.ac.id/shes

p-ISSN 2620-9284

e-ISSN 2620-9292 


\section{PENDAHULUAN}

Keterampilan berbahasa erat kaitannya dengan proses berpikir yang mendasari bahasa seseorang. Semakin jelas pemikiran seseorang maka semakin jelas pula bahasa yang digunakan. Dawson (1963 dalam Sutari 1997:3) mengutarakan bahwa melatih keterampilan berbahasa berarti melatih keterampilan berpikir. Namun siswa menganggap bahasa Indonesia adalah mata pelajaran yang mudah sehingga mereka kurang berminat untuk memperhatikan materi dalam mata pelajaran bahasa Indonesia dan nilai yang diperoleh pada mata pelajaran bahasa Indonesia adalah nilai yang rendah.

Dalam kegiatan menyimak diperlukan media pembelajaran untuk mendukung proses kegiatan belajar mengajar sehingga tercipta kualitas pembelajaran yang baik. Dengan menggunakan media pembelajaran pada proses belajar mengajar akan meningkatkan minat dan motivasi siswa untuk belajar. Media pembelajaran yang digunakan harus disesuaikan dengan materi yang akan disampaikan oleh guru.

Media audio adalah salah satu sarana yang dapat digunakan sebagai media pembelajaran khususnya digunakan untuk keterampilan menyimak. Media audio dapat digunakan untuk keperluan pembelajaran, bahkan untuk pembelajaran bahasa, pengucapan dan intonasi siswa yang menggunakan media ini lebih baik dibandingkan dengan siswa yang tidak menggunakannya. Media audio tidak hanya cocok untuk pesan aspek kognitif, namun juga sesuai untuk aspek afektif dan psikomotor (Wilkinson, 1980 dalam Kurniati, 2009:52).

Berdasarkan uraian di atas maka penulis tertarik untuk mengadakan penelitian tindakan kelas dengan judul "Pemanfaatan Media Audio untuk Meningkatkan Keterampilan Menyimak Cerita pada Siswa Kelas III SD Negeri Cibentang 02".

Berdasarkan kenyataan di lapangan maka dibutuhkan suatu perubahan tentang penggunaan media pembelajaran untuk meningkatkan kualitas pembelajaran yang berwujud hasil belajar, maka yang menjadi permasalahan utama yang hendak dipecahkan adalah :

Bagaimana cara guru menggunakan media audio agar dapat meningkatkan kualitas pembelajaran keterampilan menyimak cerita pada siswa di kelas III SD Negeri Cibentang 02?. Sesuai rumusan masalah di atas, tujuan dalam penelitian tindakan kelas ini adalah memperbaiki kualitas pembelajaran keterampilan menyimak cerita, meningkatkan proses pembelajaran dan hasil belajar pada keterampilan menyimak cerita.

\section{METODE}

Jenis penelitian PTK (Penelitian Tindakan Kelas) Sumber data dalam penelitian ini adalah siswa kelas III SD Negeri Cibentang 02 yang berjumlah 16 siswa yang terdiri dari 9 siswa laki-laki dan 7 siswa perempuan. Sebagian besar siswa kelas III SD Negeri Cibentang 02 bertempat tinggal di sekitar SD.

\section{HASIL DAN PEMBAHASAN}

Penelitian ini terdiri dari siklus I dan siklus II. Dengan uraian sebagai berikut:

Perencanaan dalam siklus I meliputi: (1) Mengidentifikasi masalah, mendiagnosis masalah, dan mengembangkan pemecahan masalah; (2) Merancang rencana pembelajaran sesuai materi pada saat pelaksanaan siklus I; (3) Merancang alat peraga, bahan, dan lembar kegiatan siswa; (4) Menyusun lembar pengamatan aktivitas belajar siswa; (5) Menyusun tes formatif I.

Pelaksanaan pembelajaran merupakan implementasi atau penerapan pada tahap sebelumnya yaitu tahap perencanaan. Pelaksanaan dalam siklus I ini meliputi: (1) Mengadakan presensi siswa; (2) Melaksanakan rancangan yang terdapat pada RPP; (3) Menggunakan alat peraga berupa media audio, bahan, dan lembar kegiatan 
siswa untuk menunjang keberhasilan proses pembelajaran; (4) Pada akhir pelaksanaan, siswa mengerjakan tes formatif I.

Sesuai dengan tujuan penelitian, maka pengamatan difokuskan pada: Aktivitas Siswa. Observasi aktivitas siswa meliputi: kehadiran peserta didik, perhatian dan sungguh-sungguh saat belajar di kelas, keberanian siswa mengajukan pertanyaan, siswa merangkum isi cerita yang disimak minimal 5 kalimat

Refleksi merupakan langkah untuk menganalisis perencanaan, pelaksanaan, observasi yang dilakukan pada siklus I. Analisis dilakukan untuk mengetahui kelebihan dan kekurangan unsur-unsur yang diamati pada siklus I.

Data kuantitatif pada penelitian ini berupa hasil tes formatif siswa setelah proses pembelajaran selesai. Data kuantitatif yang berupa angka atau nilai akhir belajar siswa..Data kualitatif pada penelitian tindakan kelas ini berupa hasil pengamatan aktivitas siswa pada saat proses pembelajaran berlangsung.

Teknik Pengumpulan Data yaitu dengan Tes Formatif Siklus I, II dan IIITes formatif merupakan alat pengukur keberhasilan siswa dalam menyerap materi pembelajaran. Tes formatif yang digunakan adalah tes yang berbentuk soal uraian.Mengobservasi siswa, Teknik observasi digunakan untuk mengukur tingkat perhatian siswa terhadap pembelajaran Observasi siswa dengan mengamati aktivitas siswa pada saat pembelajaran.

Instrumen dalam penelitian ini adalah seperangkat tes menyimak dan lembar pengamatan. Instrumen yang digunakan dalam penelitian ini berupa tugas merangkum cerita yang telah disimak. Tes adalah instrumen atau alat yang digunakan untuk memperoleh informasi tentang individu atau objek. Sebagai alat pengumpul informasi atau data, tes harus dirancang secara khusus. Kekhususan tes terlihat dari bentuk soal tes yang digunakan, jenis pertanyaan, rumusan pertanyaan yang diberikan, dan pola jawabannya harus dirancang menurut kriteria yang telah ditetapkan. Dalam kegiatan menyimak ini terdapat beberapa aspek penilaian, yaitu: pemahaman isi teks, pemahaman detil isi teks, ketepatan organisasi teks, ketepatan diksi, ketepatan struktur kalimat, ejaan dan tata tulis (Nurgiyantoro(2010:367)).

Peningkatan Hasil Belajar secara keseluruhan :

\begin{tabular}{|c|l|c|c|c|c|}
\hline No & $\begin{array}{l}\text { Nama } \\
\text { Siswa }\end{array}$ & $\begin{array}{c}\text { Nilai } \\
\text { sebelum } \\
\text { perbaikan }\end{array}$ & $\begin{array}{c}\text { Nilai } \\
\text { perbaikan } \\
\text { siklus 1 }\end{array}$ & $\begin{array}{c}\text { Nilai } \\
\text { perbaikan } \\
\text { siklus 2 }\end{array}$ & $\begin{array}{c}\text { Nilai } \\
\text { perbaikan } \\
\text { siklus 3 }\end{array}$ \\
\hline 1 & $\begin{array}{l}\text { Abdul } \\
\text { Muis }\end{array}$ & 76 & 76 & 84 & 84 \\
\hline 2 & $\begin{array}{l}\text { Ayu } \\
\text { Nabila }\end{array}$ & 76 & 86 & 88 & 88 \\
\hline 3 & Bahtiar & 68 & 74 & 82 & 82 \\
\hline 4 & $\begin{array}{l}\text { Bismi } \\
\text { Caca }\end{array}$ & 72 & 76 & 84 & 84 \\
\hline 5 & $\begin{array}{l}\text { Danu } \\
\text { Amarta }\end{array}$ & 66 & 68 & 80 & 80 \\
\hline 6 & Evi Riyanti & 68 & 74 & 74 & 80 \\
\hline 7 & M. Riyan & 60 & 68 & 74 & 74 \\
\hline 8 & M. Hasbi & 66 & 70 & 72 & 80 \\
\hline 9 & $\begin{array}{l}\text { M. Rizki } \\
\text { Adit }\end{array}$ & 52 & 54 & 60 & 74 \\
\hline 10 & Nanda & 78 & 86 & 88 & 88 \\
\hline
\end{tabular}


SHEs: Conference Series 3 (3) (2020) $10-14$

\begin{tabular}{|c|l|c|c|c|c|}
\hline 11 & $\begin{array}{l}\text { Nizam } \\
\text { Maulana }\end{array}$ & 78 & 86 & 90 & 90 \\
\hline 12 & $\begin{array}{l}\text { Raosan } \\
\text { Fikri }\end{array}$ & 50 & 52 & 60 & 70 \\
\hline 13 & $\begin{array}{l}\text { Rindu } \\
\text { Hayatun }\end{array}$ & 62 & 62 & 72 & 74 \\
\hline 14 & Shela & 62 & 64 & 72 & 74 \\
\hline 15 & $\begin{array}{l}\text { SyamsulM } \\
\text { aarif }\end{array}$ & 64 & 66 & 70 & 74 \\
\hline 16 & Salwa & 60 & 64 & 74 & 84 \\
\hline \hline & Jumlah & 1056 & 1116 & 1216 & 1282 \\
\hline$\cdot$ & Rata-rata & 66 & 70 & 76 & 80 \\
\hline
\end{tabular}

Tabel Hasil Observasi Aktivitas Siswa Secara keseluruhan :

\begin{tabular}{|c|c|c|c|c|}
\hline \multirow[t]{2}{*}{ No. } & \multirow[t]{2}{*}{$\begin{array}{ll}\text { Aspek } & \text { yang } \\
\text { diamati }\end{array}$} & $\begin{array}{l}\text { Pertemuan } \\
\text { siklus I }\end{array}$ & $\begin{array}{l}\text { Pertemuan } \\
\text { siklus II }\end{array}$ & $\begin{array}{l}\text { Pertemuan } \\
\text { siklus III }\end{array}$ \\
\hline & & Rata-rata & Rata-rata & Rata-rata \\
\hline 1 & $\begin{array}{l}\text { Keaktifan siswa } \\
\text { pada saat } \\
\text { pembelajaran }\end{array}$ & $3,6 \%$ & $3,7 \%$ & $3,8 \%$ \\
\hline 2 & $\begin{array}{l}\text { Kerja sama } \\
\text { antar siswa }\end{array}$ & $3,1 \%$ & $3,3 \%$ & $3,4 \%$ \\
\hline 3 & $\begin{array}{l}\text { Keberanian } \\
\text { siswa untuk } \\
\text { mengemukakan } \\
\text { pendapat }\end{array}$ & $3,2 \%$ & $3,3 \%$ & $3,7 \%$ \\
\hline 4 & $\begin{array}{l}\text { Ketepatan } \\
\text { siswa } \\
\text { untukmenjawab }\end{array}$ & $3,3 \%$ & $3,4 \%$ & $3,6 \%$ \\
\hline 5 & $\begin{array}{lr}\text { Sikap siswa } \\
\text { pada saat } \\
\text { pembelajaran }\end{array}$ & $3,7 \%$ & $3,8 \%$ & $3,8 \%$ \\
\hline
\end{tabular}

\section{SIMPULAN}

Berdasarkan hasil analisis dan pembahasan penelitian tindakan kelas ini, maka peneliti menyimpulkan bahwa terdapat peningkatan hasil belajar siswa dan aktivitas siswa pada pembelajaran keterampilan menyimak cerita pada siswa kelas III SD Negeri Cibentang 02. Peningkatan pada pembelajaran keterampilan menyimak cerita dapat diketahui dari hasil tes pratindakan, siklus I, siklus II dan siklus III. Nilai rata-rata pada pratindakan adalah 66 dengan persentase ketuntasan sebesar $31 \%$. Pada siklus I nilai rata-rata kelas menjadi 70 dengan persentase ketuntasan sebesar $80 \%$.

Setelah dilaksanakan siklus II nilai rata-rata kelas menjadi 76 dan persentase ketuntasan belajar menjadi $81 \%$. Pada siklus III nilai rata-rata 80 dan persentase ketuntasan belajar menjadi $91 \%$. Dengan demikian ada terdapat peningkatan dari siklus I ke siklus II ke siklus III. Peningkatan nilai rata-rata 80 dan prosentase ketuntasan belajar menjadi $91 \%$, ini membuktikan keberhasilan pembelajaran keterampilan menyimak cerita dengan menggunakan media audio. 
SHEs: Conference Series 3 (3) (2020) $10-14$

\section{DAFTAR PUSTAKA}

Arsyad, Azhar. 2015. Media Pembelajaran. Jakarta: PT Raja Grafindo Persada Mulyasa, E. 2009. Menjadi Guru Profesional. Bandung: PT Remaja Rosdakarya.

Mulyasa, H.E. dkk. 2010. Praktik Penelitian Tindakan Kelas. Bandung: PT Remaja Rosdakarya.

Nurgiyantoro, B. 2010. Penilaian Pembelajaran Bahasa. Yogyakarta: BPFE Yogyakarta. 